\title{
The basic space of a revolutionary parliament: Scaling the Frankfurt Assembly of $1848 / 49$
}

\author{
Michael Herrmann \\ University of Konstanz, Germany \\ Ulrich Sieberer \\ University of Bamberg, Germany
}

\begin{abstract}
We examine whether there is a basic space in a parliament which grew out of a revolution and had no prior history of parliamentarism: the Frankfurt Assembly of 1848/49. We scale all 299 roll call votes to determine the dimensionality of voting as well as the positions of deputies and their party groups. We find two dimensions of disagreement and show that they can be interpreted in line with historical scholarship as conflict over who should govern (the people or the monarch) and conflict over state borders (inclusion or exclusion of Austria). We find that the party groups line up on the first dimension in ways consistent with historical scholarship on their political inclinations, but we also find wide variation in deputies' positions within and across parties. Moreover, deputies' positions turn out to be polarized on the territorial dimension but not on the government dimension. We conclude that ideological constraint was the primary structuring force in parliamentary voting. Our results underscore the pervasiveness of low dimensionality in parliamentary voting even in the absence of strong parties and agenda control.
\end{abstract}

\section{Keywords}

Germany, ideal point estimation, ideology, 19th century, roll call voting

\section{Introduction}

One of the most striking findings in the study of parliaments is that MPs vote very similarly across different bills. A substantial literature documents that voting in many contemporary (Bräuninger et al., 2016; Curini and Zucchini, 2012; Desposato, 2006; Godbout and Høyland, 2011; Hix and Jun, 2009; Hix and Noury, 2016; Hix et al., 2005; Poole and Rosenthal, 1991; Voeten, 2013) and historic (Alemán and Saiegh, 2014; Clinton and Meirowitz, 2004; Dougherty and Heckelman, 2006; Häge, 2019; Hansen and Debus, 2012; Poole and Rosenthal, 1991; Pope and Treier, 2011; Rosenthal and Voeten, 2004; SchonhardtBailey, 2003) parliaments and assemblies can be reduced to one or at most two fundamental dimensions of disagreement, commonly referred to as 'basic space' (Armstrong et al., 2014; Hinich and Munger, 1994; Poole, 2005). Despite this wealth of evidence, previous research has mostly looked at established parliaments. In contrast, this study considers a novel parliament which was founded at a revolutionary moment and had no prior history of parliamentarism: the Frankfurt Assembly (FA) of 1848/49.

The FA (also, Frankfurt Parliament) is an interesting case for basic space theory because it represents parliament in its primitive state. Unlike many other 19th-century parliaments, which evolved slowly and gradually, the FA was the result of revolution. It came into being on the spur of a moment, at a time when parliamentarism had not yet existed in Germany, except locally in a few states. Political parties, likewise, had not existed in Germany prior to 1848 . Most of the Frankfurt deputies were therefore complete newcomers with little or no prior parliamentary experience. Moreover, the FA was a large and diverse assembly which drew MPs from a territory twice as large as today's

\section{Corresponding author:}

Michael Herrmann, University of Konstanz, Department of Politics and Public Administration, Box 83, D-78457 Konstanz, Germany.

Email: michael.herrmann@uni-konstanz.de 
Germany. Over 800 MPs served in the FA in its 14-month lifetime. This large and a priori unorganized body had to decide in a very short time on complex constitutional matters with potentially large consequences. Even though the FA quickly developed party groups which played an important role in parliamentary life, plenary voting was, by and large, unrestricted, thresholds for motions and amendments were low, and parties had little means to enforce voting discipline. Its nascent nature makes the FA a least likely case for a basic space in legislative voting as some of the main drivers of such a space - most notably, strong party discipline and agenda control - were absent.

We scale the FA's entire roll call record and find strong evidence that voting can be reduced to two dimensions of disagreement. Based on key votes, we show that the predominant dimension represents disagreement over authority (republican left, liberal right and monarchist far right) and that the second dimension represents disagreement over territorial boundaries (inclusion vs. exclusion of Austria). This interpretation of the two dimensions is in line with historical scholarship on the FA, and it validates and extends results from earlier, less sophisticated scaling attempts which considered only a fraction of votes and MPs (Best, 1990; Best and Zimmermann, 1991; Mattheisen, 1979).

We also find large variation in MPs' positions on both dimensions, across parties, and within parties. Despite such variation, the parties can be lined up on the first dimension in ways consistent with historical accounts of their political inclinations. On the territorial dimension, we find MPs from republican parties to one side and MPs from liberal and conservative parties divided. Comparing MPs' recovered positions to those from previous scaling attempts (Best, 1990; Best and Zimmermann, 1991; Mattheisen, 1979), we find stark differences in the distributions of ideal points on both dimensions, suggesting a different interpretation of the nature of disagreement in the FA. We conclude, based on our findings and the historical record on the FA, that MPs' shared values and beliefs are the most likely explanation for the strong basic space in voting.

Our analysis demonstrates that the basic space theory of parliamentary voting extends to a 'freshmen' parliament in the revolutionary setting of 19 th-century Germany. It thus adds to previous analyses demonstrating basic spaces in established historic parliaments (Alemán and Saiegh, 2014; Clinton and Meirowitz, 2004; Dougherty and Heckelman, 2006; Häge, 2019; Hansen and Debus, 2012; Poole and Rosenthal, 1991; Pope and Treier, 2011; Rosenthal and Voeten, 2004; Schonhardt-Bailey, 2003). In contrast to many previous studies, our results provide an example of a basic voting space which arises almost solely from constraints on MPs' political preferences rather than party discipline or agenda control. The existence of a basic space in such a hard case as the FA yields a striking example for the pervasiveness of the low dimensionality of legislative voting.

Our findings also provide new evidence on a much studied institution in German parliamentary history. Most previous research on the FA has used MPs' membership in parliamentary party groups as the primary criterion for inferring their political leanings (e.g. Eyck, 1968; Hildebrandt, 1986; Koch et al., 1989). In scaling the entire voting record, we validate these conceptions of MPs' political leanings, we improve upon them by revealing the diversity of opinion within and between party groups as well as among MPs with no party affiliation, and we also correct previous roll-call-based estimates of MPs' positions in substantively important ways.

\section{Basic space theory and the FA}

The basic space literature provides three major arguments for why parliamentary voting is low dimensional. The first argument is ideology. MPs, according to this argument, vote in line with their issue preferences. These preferences are correlated such that an MP's stance on one issue is constrained by his or her position on other issues (Converse, 1964; Hinich and Munger, 1994; Poole, 2005). If MPs share the same constraints on their issue preferences, their voting patterns will be correlated such that MPs with similar preferences on one issue will tend to vote together on other issues. Such similarity in voting gives rise to a low dimensional space, in which MPs can be mapped according to their general ideology (Armstrong et al., 2014; Poole, 2005).

Party loyalty is another factor which may reduce the dimensionality of voting. According to this argument, MPs vote in line with their party in order to secure benefits such as support in the electoral arena or career advancement (Aldrich, 1995; Bowler, 2000; Cox and McCubbins, 1993). Loyalty reduces the dimensionality of the voting space as members of the same party vote the same way across issues (Jenkins, 1999; Poole and Rosenthal, 1997).

A third argument in favour of a low dimensional voting space is agenda control. Accordingly, MPs collectively vote strategically in order to monopolize control over the parliamentary agenda and to secure cabinet positions (Diermeier and Feddersen, 1998; Kam, 2009). Thus, MPs from government parties support proposals by the cabinet and vote down opposition proposals. Such voting often gives rise to an additional dimension, dividing government parties from opposition parties (Alemán and Saiegh, 2014; Bräuninger et al., 2016; Hix and Noury, 2016; Spirling and McLean, 2007).

In light of these arguments, the FA represents an unlikely case for observing a basic space in voting. For one thing, the lack of strong party organizations in 1848 means that two drivers of a basic space - party pressure and agenda control - were virtually absent, or at least very 
weak. Parliamentarism and political parties had not existed in Germany prior to 1848 (Boldt, 1971: 44-53; Kramer, 1968: 16-73; Langewiesche, 1978: 329) and elections to the FA were entirely non-partisan (Kramer, 1968: 74; Langewiesche, 1978: 331-32). Thus, the Frankfurt deputies did not belong or owe their allegiance to political organizations. Although deputies quickly formed party groups, as we shall see below, membership in these groups was entirely voluntary, party switching was frequent, and many MPs did not join any party (Best and Weege, 1996; Koch et al., 1989).

This leaves ideology as the main structuring force, but even this factor is likely to be weak. As the following sections will show, the FA was a large assembly which brought together MPs from a territory twice the size of today's Germany. Elected MPs came to Frankfurt in a rush, with little to no time to prepare for the task which lay ahead of them and which involved many decisions on technical issues including constitutional law, civil rights or trade regulation. Despite being well educated, most MPs were first-time politicians with no prior parliamentary experience ( $82 \%$, according to Best, 1990: 191). While diversity and lack of experience does not prevent deputies from holding opinions on Germany's political future, for those opinions to manifest themselves in patterns of floor voting, MPs needed to know how their opinions translate into actual policies - a connection which even expert politicians sometimes find difficult to make (Ringe, 2005).

\section{The FA $1848 / 49$}

The Frankfurt Parliament was the key institution of the failed revolution of $1848 .{ }^{1}$ Massive popular upheavals all over Germany in March 1848 had put the old regimes on the defence. On 21 March, Frederick William IV of Prussia, head of the dominant military power in Germany, publicly announced his openness to liberal reforms. On 31 March, over 500 political reformers, who had been summoned by a small group of south western German liberals, met at St. Paul's Church in Frankfurt (the so-called Pre-Parliament) and decided to hold elections for a national assembly whose task should be the drafting of a constitution for an allGerman state.

Elections to the FA were carried out from mid-April through May 1848. MPs were elected by universal male suffrage in single-member districts, mostly through indirect elections (Botzenhart, 1977: 141-63). Elected deputies came from all over the German-speaking territories, including German parts of the Austro-Hungarian Empire. Most elected deputies were local dignitaries: well educated and esteemed individuals; but few of them were experienced in parliamentary matters (Eyck, 1968: 93-4). On 18 May, the Frankfurt Parliament solemnly convened for its first session at St. Paul's Church in Frankfurt.
Overall, the FA was a very active parliament. The sheer volume of the parliamentary minutes (Wigard, 1849), which are almost 7000 pages long, testifies to the FA's busyness. Within 14 months, MPs delivered hundreds of speeches, submitted proposals, moved amendments and voted in 299 roll call votes. The FA's primary approach in legislative decision-making was to consider constitutional articles on an issue-by-issue basis. As a result, many votes concerned single constitutional articles and provisions. Package votes were rare. Many votes on important constitutional matters were roll call votes, and many of them were decided by close margins.

The political debate in the FA revolved around two fundamental questions: how to govern a future German state, and how to draw its borders (Eyck, 1968; Hildebrandt, 1986; Ribhegge, 1998). On the first issue, the parliament was divided into radical democrats on the left, and liberals and conservatives on the right (Hildebrandt, 1986: 59-72; Eyck, 1968: 119-50). The radical left advocated complete popular sovereignty and abolition of monarchist rule. The liberals, on the other hand, sought to preserve hereditary monarchy and to hedge it with a constitutional framework which would provide legal protection from feudal order and parliamentary representation for the middle classes through restricted voting rights. A small group of conservative MPs, mostly members of aristocracy, rejected democratic reforms and sought to preserve the old order.

The second question divided proponents of a so-called Greater Germany (Großdeutsche) and Lesser Germany (Kleindeutsche; Eyck, 1968: 363). For many MPs in the Greater Germany group, citizenship was fundamentally a matter of identity and shared culture. For them, only language could delineate state boundaries. Supporters of this position included MPs of the radical left and the far right as well as parts of the liberal camp (Hildebrandt, 1986: 200). Most of them were Catholic and from southern German states, including Austria (Ribhegge, 1998: 120). A chief political problem with this groups' notion of citizenship was that it included only parts of the AustroHungarian Empire. It was hard to conceive the Habsburg Monarchy break up and make way for a German nation state, especially after it became clear in early November that reactionary forces had struck down democratic revolutionaries in Vienna. Many liberals as well as some MPs of the moderate left thus took a more pragmatic approach to citizenship which excluded Austria - permanently or temporarily - from a future German state. These MPs, who were mostly Protestants and from northern German states, sought to make the king of Prussia hereditary emperor (Eyck, 1968: 363).

A defining feature of the FA was that deputies quickly sorted themselves into parliamentary groups to which they referred as 'clubs' or 'parties'. ${ }^{2}$ Each group named itself after the local inn at which it held its meetings. Historians order these early parliamentary parties according to their 


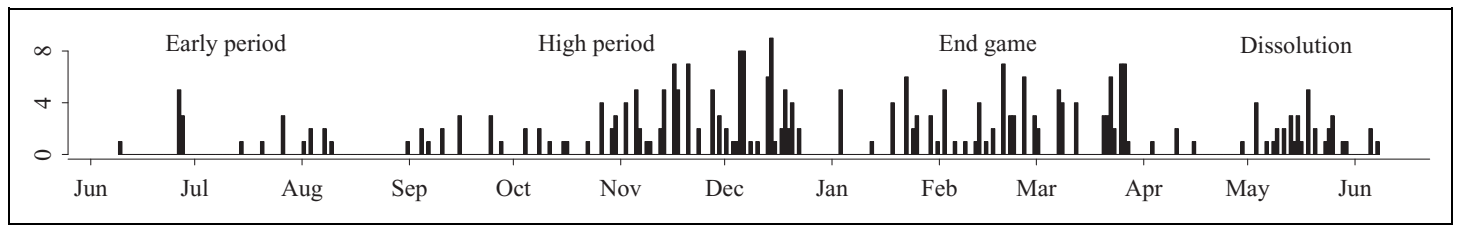

Figure I. When did votes take place? Number of roll call votes per day over the course of the Frankfurt Assembly.

political orientation from left to right as follows (cf. Boldt, 1971; Eyck, 1968; Hildebrandt, 1986; Kramer, 1968; Ribhegge, 1998): Donnersberg, Deutscher Hof, Westendhall, Württemberger Hof, Augsburger Hof, Landsberg, Casino and Café Milani. All parties had standing orders, membership lists and brief political manifestos (Boldt, 1971: 163-92). During meetings, members discussed the issues of the day, prepared and coordinated plenary proposals and decided on how they would vote in upcoming plenary sessions (for detailed descriptions, see Kramer, 1968: 79-88). It is unclear how much control these early parties exerted over their members' plenary behaviour (Eyck, 1968: 296; and in particular Kramer, 1968: 99-101). Each party's standing orders required members to refrain from introducing motions or amendments without prior discussion in the caucus. They also demanded that members vote with their party if the caucus decided to treat a motion as a party vote. Yet, the parties had little means to sanction their members other than expelling them, which rarely happened (Botzenhart, 1977: 430). Overall, party switching was quite frequent and several parties went through internal splits. For example, the Augsburger Hof and the Landsberg resulted from splits within the Württemberger Hof and the Casino party, respectively. Finally, many MPs chose not to affiliate themselves with any parliamentary group (Best, 1990; Koch et al., 1989).

The political life course of the FA unfolded roughly in four stages: an unsettled early period from May to August, a high period of intensive work from September to December, a climactic endgame from January to March 1849 and a dissolution period from April to June 1849. Figure 1 shows the distribution of votes over the four periods.

In the early period, MPs sorted themselves into parties and struggled to organize parliamentary business (Eyck, 1968: 102-57). They created standing committees, elected a president of the assembly and created a provisional executive power headed by a so-called Vicar of the Empire (Ribhegge, 1998: 38-41), whose task was to enforce the FA's decisions. Chief among the committees was the constitutional committee which was endowed with the task of drafting a legal framework for a future government (Eyck, 1968: 206-14).

The high period was marked by a high degree of parliamentary organization. Most MPs had sorted themselves into parties which played a major role in structuring legislative business (Botzenhart, 1977: 418-27, 436-41). Votes during this period were numerous and concerned mainly basic civil rights and trade regulations (Eyck, 1968: 20653). The key achievement of this period was the passage of the bill of rights on 21 December, and its proclamation on 27 December 1848 (Ribhegge, 1998: 50).

The most difficult questions came up in the third phase (see, e.g. Ribhegge, 1998: 121-41). During this period, MPs struggled to reach an agreement over the form of a future government. In addition, the conflict over the inclusion of Austria became salient. The FA reached a state of gridlock until a bargain was struck in late March 1849 which finally enabled passage of the constitution (see, e.g. Eyck, 1968: 357-74): In the so-called Simon-Gagern pact, a group of liberal MPs led by Heinrich von Gagern pledged themselves to support a suspensive veto by the emperor over parliamentary legislation (as opposed to an absolute veto), as well as voting rights for all male citizens (as opposed to restricted suffrage); in return, a group of moderate leftists led by Heinrich Simon promised their support for a Lesser German state ruled by Frederick William IV as hereditary monarch. On 27 March, the FA passed the motion to install a parliamentary hereditary monarchy and one day later elected the king of Prussia emperor of Germany.

Frederick William IV refused the crown offered to him on 3 April 1849. By that time, the revolution had already lost its early momentum and restorative forces were back on the rise (for an account of the events, see, e.g. Ribhegge, 1998: 142). In early May, the FA prompted, in a last attempt, all German governments and the German people to implement the constitution and to hold elections for parliament in mid-July. On 14 May, the Prussian government forbade Frankfurt MPs to carry out their mandate and requested the Vicar of the Empire to shut down the FA. Most right-wing MPs quickly left Frankfurt, while more radical democrats stayed and continued parliamentary business. In early June, they abandoned Frankfurt for fear of political prosecution and moved the parliament to Stuttgart. On 18 June, this so-called Rump Parliament was shut down by Württembergian troops.

\section{Previous attempts to scale the FA}

Given its prominence in German parliamentary history, the FA has generated much scholarly interest. Here, we review previous attempts to infer the dimensionality of political conflict and MPs' positions from the roll call record, showing that previous work analysed but a fraction of the roll 
call record and made use of methods which are likely to bias its results.

Donald Mattheisen is, to our knowledge, the first to scale roll call votes from the FA. Mattheisen (1979) looked at a subset of 150 votes, chosen to include every major issue voted upon. He found that 84 of these votes form a Guttman scale (Guttman, 1944) on which 455 MPs could be placed according to their general ideology (i.e. republican, liberal, monarchist). Of the remaining 66 votes, 11 formed a Guttman scale related to the territorial question of Greater versus Lesser Germany, and the other 55 votes could not be scaled (Mattheisen, 1979: 128-9). Mattheisen's finding that substantial portions of the roll call record form two Guttman scales was the first evidence of a basic structure underlying voting behaviour in the FA.

Eleven years after Mattheisen, Heinrich Best analysed the behaviour of 766 MPs in 98 roll call votes (Best, 1990). The votes were a random selection from the entire voting record (Best, 1990: 495), and drawn independently of Mattheisen's earlier efforts. Best applied factor analysis to the voting data and found two principal components, which he interpreted in the same way as Mattheisen. In subsequent work, Best and Zimmermann (1991) reanalysed 90 of the above roll call votes using Mokken scaling (Mokken, 1971). They found that 51 of the votes can be attributed to a political ideology scale, 5 can be attributed to a Greater versus Lesser Germany scale and 28 of the votes can be attributed to both scales (Best and Zimmermann, 1991: 65, 76).

Taken together, these analyses suggest that portions of the FA's voting record can be summarized by two dimensions on which MPs can be placed according to their political views. However, they suffer from two interrelated shortcomings: consideration of only a fraction of the voting record, and lack of a well-developed method for recovering MPs' political preferences (i.e. their ideal points). These limitations are likely to bias previous results.

First, previous research could only analyse a fraction of the roll call record, due to grave limitations in computer memory (Best, 1990: 493). Using fewer votes, however, means that prior studies could only scale a subset of MPs. As we explain below, many FA deputies did not serve throughout the entire 14-month period: due to absences, dropouts, and replacements, the number of votes cast by each MP varies widely (see Figure 2, top graph). If one decides to restrict the analysis to only a subset of votes, one loses MPs who did not serve at the time these votes were taken or who participated in too few of them to be subjected to statistical analysis. Since previous scaling methods required complete voting records, even MPs who missed but one of the selected votes had to be dropped from the analysis. The result of such an analysis is likely to reflect the views of MPs with long voting records at the neglect of those with shorter tenure periods.

The problem of missing entries was recognized by Best and his co-authors who tried to deal with it by filling in

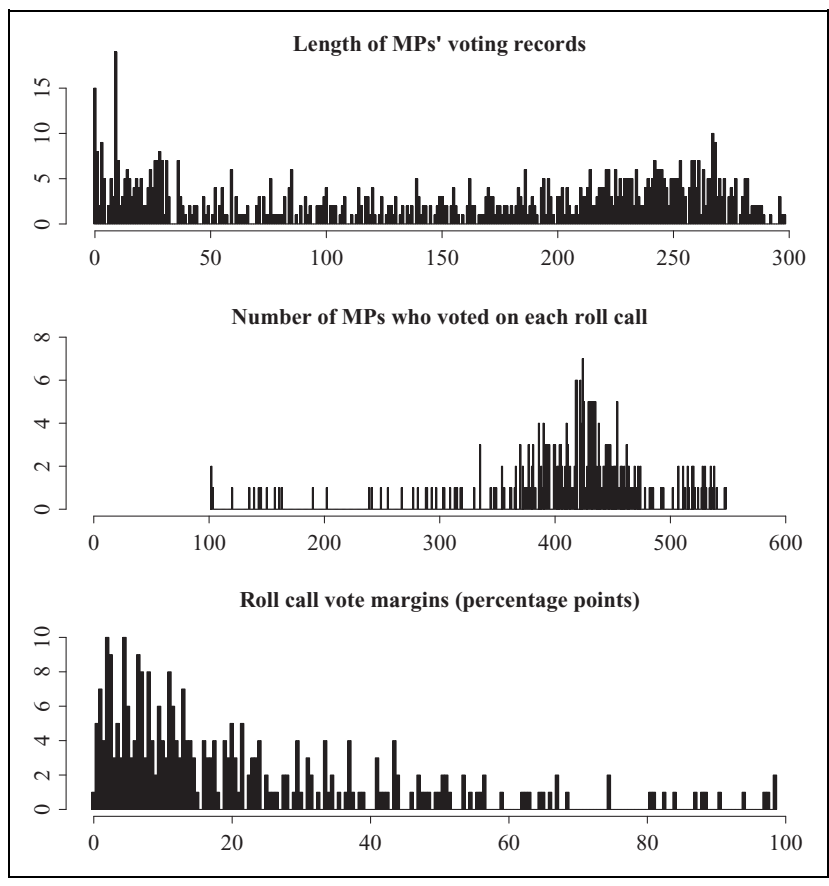

Figure 2. Informativeness of roll call data.

empty cells in MPs' voting records based on how other MPs with similar voting records voted on a given motion (Best, 1990: 499-511). Imputation of such hypothetical votes enabled them to scale many more MPs than Mattheisen could. While their approach is not an unreasonable one, we believe it is likely to exaggerate patterns in voting behaviour. Imputation of missing entries based on how MPs with similar voting histories decided tends to make the voting records of those MPs more similar. In subsequent scaling analyses, this should increase the likelihood of finding an underlying structure in the voting record. The increased similarity also means that the scaling procedure should locate MPs with incomplete records closer to those with complete records than their observed voting behaviour would suggest, thus understating the diversity of political opinion. ${ }^{3}$

Third, previous studies relied on scaling methods which are, by today's standards, outdated. Today's methods supersede Guttman scaling by allowing for 'errors' in voting records (i.e. MPs do not always vote perfectly in line with their ideology; see, e.g. Poole, 2005). Modern methods of roll call analysis also provide a theoretical basis for interpreting the recovered positions of MPs as ideal points (Clinton et al., 2004; Poole, 2005). Mokken scaling and factor analysis do not have this property. Factor analysis is not even an unfolding technique, which means it does not produce a space in which distances between points can be interpreted as similarities (van Schuur and Kiers, 1994). ${ }^{4}$ Moreover, today's methods do not require complete voting records or imputation of missing votes. Shorter voting 
records only make an MP's position less certain compared to those of other MPs.

Lastly, we do not know if the basic space found in previous studies actually applies to all roll call votes. This is an important limitation as basic space theory predicts similar voting patterns across different bills. A scaling of the entire roll call record allows for a more comprehensive test and greater insight into the pervasiveness of the phenomenon than previous studies could provide.

\section{The roll call record}

Roll call votes in the FA could come about in one of two ways (Wigard, 1849: 165): According to standing order $\S$ 42 , a roll call could be requested by any deputy and required the support of at least 50 deputies (i.e. 10-14\% of the plenum, given common attendance levels, see Figure 2). Alternatively, the FA presidium could initiate a roll call in line with standing order $\S 41$, which required that votes be counted if the result of voting via standing up and remaining seated (and vice versa) was indeterminate. Together, this means that roll call votes were likely to arise on important and divisive issues which engaged a significant number of MPs (Häge, 2019).

One concern about the use of roll call data in general is that party leaders may initiate such votes strategically in order to put pressure on their fellow party members (Carrubba et al., 2006, 2008), which would lead to an underestimation of preference heterogeneity within parties. We believe such an argument does not hold for the FA for a number of reasons, which we discuss at length in the Online Supporting Information (SI). First, party leaders had very little power to sanction dissenting fellow partisans, and the many party splits suggest that MPs voluntarily associated themselves with others and could not be coerced into voting a certain way. Second, the parties (and thus party leaders) did not enjoy formal prerogatives in parliamentary business and attempts to establish the parties as parliamentary actors all died on the floor (Botzenhart, 1977: 437-41; Kramer, 1968: 198-200). Third, most party leaders could not use $\S 42$ to force a roll call on their fellow party members, as the high threshold of 50 deputies would have made such an attempt subject to near unanimous consent by their fellow partisans, or outright impossible because their party was too small. Fourth, a qualitative analysis of the parliamentary minutes yields no evidence to support the idea that the FA presidium used $\S 41$ to initiate roll calls under the false pretence of an unclear voting outcome, and our scaling results are unaffected by whether we include or exclude roll call votes initiated by the presidium.

We identified all 299 roll call votes through the index of the parliamentary minutes (Wigard, 1849; Sachregister, 47-9). ${ }^{5}$ For each vote, we recorded its date, page number, motion title (see the SI for a listing of all motion titles), whether the vote was initiated according to $\S 41$ or $\S 42$,
Table I. Breakdown of voting data: 299 votes and 809 MPs.

\begin{tabular}{|c|c|c|c|c|c|c|}
\hline \multirow[b]{2}{*}{ Yes } & \multicolumn{2}{|c|}{ Raw entries } & \multicolumn{2}{|c|}{$\begin{array}{c}\text { Processed } \\
\text { entries }\end{array}$} & \multicolumn{2}{|c|}{$\begin{array}{l}\text { Used for } \\
\text { scaling }\end{array}$} \\
\hline & 59,246 & $24.5 \%$ & 59,246 & $24.5 \%$ & 59,246 & $48.0 \%$ \\
\hline No & 63,453 & $26.2 \%$ & 63,701 & $26.3 \%$ & 63,701 & $51.6 \%$ \\
\hline Abstain & 702 & $0.3 \%$ & 454 & $0.2 \%$ & & \\
\hline Absent & 3305 & $1.4 \%$ & & & & \\
\hline $\begin{array}{l}\text { Absent w } \\
\text { apology }\end{array}$ & 9711 & $4.0 \%$ & & & & \\
\hline $\begin{array}{c}\text { Absent w/o } \\
\text { apology }\end{array}$ & 11,232 & $4.6 \%$ & & & & \\
\hline MP not listed & 94,242 & $39.0 \%$ & 118,490 & $49.0 \%$ & & \\
\hline
\end{tabular}

and whether an MP voted 'yes', 'no', abstained, was absent, or went unmentioned in the vote tally. The SI provides a scan of a roll call vote for illustration. Overall, the roll call record mentions the names of 809 MPs, which gives us a roll call matrix with $241,891(809 \times 299)$ cells. Table 1 shows a breakdown of the data. The first two columns give the distribution of the entries as they appear in the voting record. The third and fourth columns show the breakdown after collapsing absences into one category, and recoding abstentions on the vote for emperor as 'no' (see below). The last two columns of Table 1 show a breakdown of the data used in the scaling analysis.

Two things are apparent from Table 1. First, MPs rarely abstained from voting. The one exception is the vote for emperor in which 290 MPs voted for Frederick William, IV of Prussia while the remaining 248 MPs abstained. Following historical scholarship, which interprets abstention on the vote of emperor as 'no' (see, e.g. Eyck, 1968; Koch et al., 1989; Kramer, 1968), we end up with 454 abstentions overall, fewer than two per roll call. If there was a roll call, MPs voted.

Second, half of the cells in the roll call matrix remain empty because of absenteeism, incomplete tenure and turnover of MPs. Fluctuation of membership was a characteristic feature of the FA. As Ribhegge (1998: 36) notes, when the FA convened for its first session in May, about 300 of the 585 elected deputies had arrived in Frankfurt. By the time the last elected representatives arrived in August 'a considerable number of MPs had already resigned' (Eyck, 1968: 90). Such fluctuation of membership did not cease after the first 3 months so that the number of active MPs throughout the course of the FA was roughly between 400 and 500 (Ribhegge, 1998: 36). Eyck (1968) contends that the high turnover rates in the FA should not be surprising given the novelty of the situation and the costs to deputies of putting down their professional occupation and taking up residence in Frankfurt. Few foresaw how straining parliamentary business would be or how long it would take (Eyck, 1968: 91-2). Vacant seats were filled either by election or by sending the second place candidate as substitute.

Missing entries in roll call data can pose problems for ideal point estimation in three ways: MPs may participate 
in too few votes; roll calls may be voted on by too few MPs; and roll calls may be lopsided (i.e. nothing can be learned about MPs' preferences if nearly everybody votes the same way). Figure 2 examines all three possibilities (see the SI for complete MP-by-MP and vote-by-vote tallies). It shows that the roll call data are quite informative despite the large number of missing entries. Information is sparse for a small number of MPs and a few very lopsided roll call votes, while the number of observed votes per roll call is consistently high. ${ }^{6}$ Regarding MPs' voting records, Figure 2 shows that 15 MPs did not submit a single vote. Their ideal points cannot be recovered. Furthermore, a substantial fraction of MPs submitted only very few votes. Below, we shall pay special attention to those MPs.

Lastly, we recorded MPs' party affiliations. These affiliations were fluctuating as MPs often switched parties (see, e.g. Boldt, 1971; Eyck, 1968; Kramer, 1968). Since historical sources and previous scholarship do not always agree on the political affiliations of individual MPs, we created two codings of party membership. The first is based on Best and Weege's handbook of members of the FA (Best and Weege, 1996); $;^{7}$ the other is based on the handbook of members of the FA put together by Koch and colleagues (Koch et al., 1989). Both codings record party membership as of October 1848, and distinguish between the eight main parties introduced in section 3. The SI shows the distribution of MPs across parties according to each source.

\section{The scaling method}

We use standard Bayesian ideal point estimation (Clinton et al., 2004; Jackman, 2015) to recover the basic dimensions of conflict and MPs' political positions (for comparison, we also considered NOMINATE; see the SI). We assume that MPs have fixed positions, that is, their ideal points do not change over the course of their service in the FA.

Some cut-off is needed for including a deputy in the analysis, as their voting records differ greatly in length. We settled for a minimum value of five votes (see the SI for details). Since any decision on a cut-off value is ultimately subjective, we take the length of MPs' voting records into account when presenting our estimates. In particular, we visually de-emphasize MPs who participated in fewer votes. Overall, we scale 770 MPs and 299 roll calls.

MPs' positions and roll call locations are only identified in relation to each other; to identify the spatial map, one needs to fix the positions of either some MPs or roll calls (see, e.g. Armstrong et al., 2014; Jackman, 2001). Choosing specific positions for particular MPs is difficult in our case because our aim below is to estimate a twodimensional model. With two dimensions, one must fix the positions of three MPs such that they span a triangle. However, it is not clear what values to assign to individual MPs. While the historical record is sufficiently rich to help us

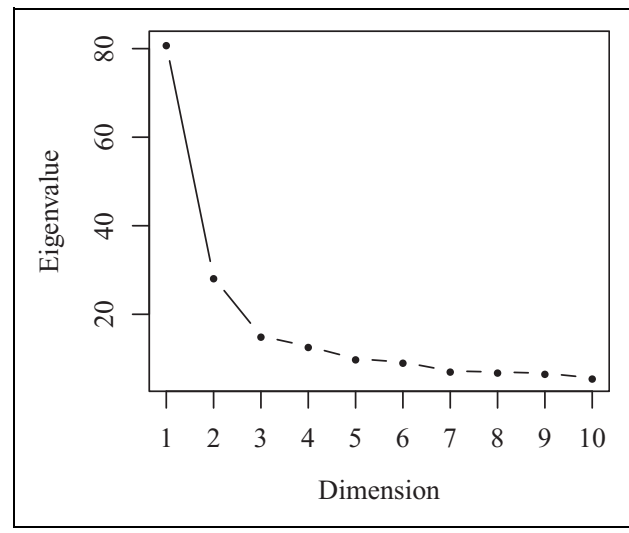

Figure 3. Scree plot of the first 10 eigenvalues of the doublecentred agreement score matrix.

select three individuals whose positions can be broadly distinguished in terms of republican and monarchist, and Greater and Lesser Germany, the historical record is clearly insufficient for determining those MPs' distances to each other (i.e. the exact shape of the triangle). ${ }^{8}$

Instead of fixing the positions of specific MPs, we use substantive knowledge about the content of two motions to identify the model (for a general discussion of this approach, see Jackman, 2001). Specifically, we fix the locations of two landmark decisions such that they are perpendicular to the $x$ - and $y$-axes: the vote on the emperor's veto rights, which we make perpendicular to the $x$-axis, and the vote on Heinrich von Gagern's proposal to enter negotiations with Austria, which we make perpendicular to the $y$-axis. As we explain in the next section, fixing these two votes lends a clean interpretation to the spatial configuration of MPs. Further technical details on the estimation are provided in the SI.

\section{Results: Dimensions and MPs' positions}

\section{Two dimensions}

To determine the dimensionality of the roll call record, we computed the eigenvalues of the double-centred matrix of MPs' agreement scores (Poole, 2005: 21-4). Figure 3 plots the 10 largest eigenvalues in descending order. By inspection, they exhibit an 'elbow': the eigenvalues fall-off smoothly from the 3 rd to the 10 th value. According to Poole (2005: 146), this is a clear indication of two dimensions.

Comparing the results of a one-, two- and threedimensional scaling of the roll call record, we find each to correctly predict 87,91 and $92 \%$ of observed votes, respectively. Model fit thus improves substantially by going from one to two dimensions, while allowing for a third dimension only yields a minor improvement. Taken together, this suggests that voting in the FA can be accurately described by two dimensions. 


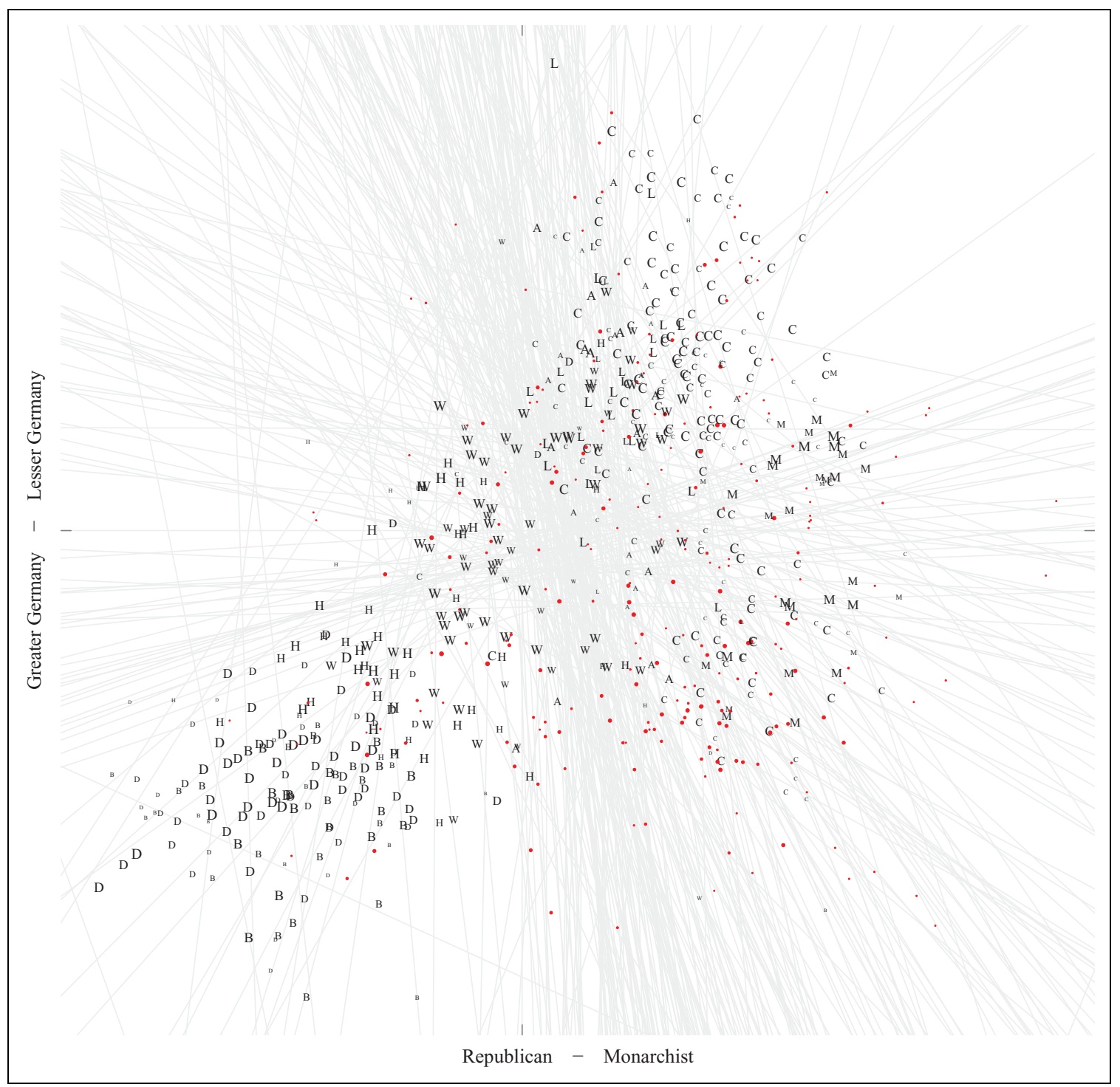

Figure 4. A political map of the Frankfurt Assembly. Points and letters represent MPs, with letters indicating party affiliation: Augsburger Hof (A), Donnersberg (B), Casino (C), Deutscher Hof (D), Westendhall (H), Landsberg (L), Café Milani (M), Württemberger Hof (W). Marker size is proportional to the number of votes submitted by an MP (at least five). Each roll call is represented by a cutting line dividing MPs who are predicted to vote in opposite ways. Tick marks indicate locations of roll calls used to identify the model: the vote on the emperor's veto (cutting line orthogonal to $x$-axis) and the vote on entering negotiations with Austria (cutting line orthogonal to $y$-axis). 770 MPs and 299 votes.

\section{A political map of the $F A$}

Figure 4 presents the result of our two-dimensional scaling of the FA. Each point or letter represents an MP, with letters indicating party affiliation according to Best and Weege (1996) and points indicating unaffiliated deputies. MPs with shorter voting records are represented by smaller markers since their positions are less certain. Each roll call is represented by a cutting line. MPs to one side are predicted to vote 'yes', those to the other side are predicted to vote 'no'.

Figure 4 shows the wide diversity of opinion in the FA. Overall, MPs are densely distributed on both dimensions and only cluster slightly in the upper-right, lower-right and lower-left quadrants. In the lower-left quadrant, we find mostly MPs from the radical democratic parties (Donnersberg and Deutscher Hof) who favoured popular sovereignty and a Greater German state. On the right, we find MPs from the liberal Casino party and the conservative Café Milani party split between the upper and lower quadrants. As the cutting lines show, voting was not one-dimensional. Although a large number of votes divided MPs in fairly similar ways - mostly along the first dimension - a substantial number of votes runs against the dominant pattern.

We interpret the two dimensions in Figure 4 as republican versus monarchist and Greater versus Lesser Germany. 


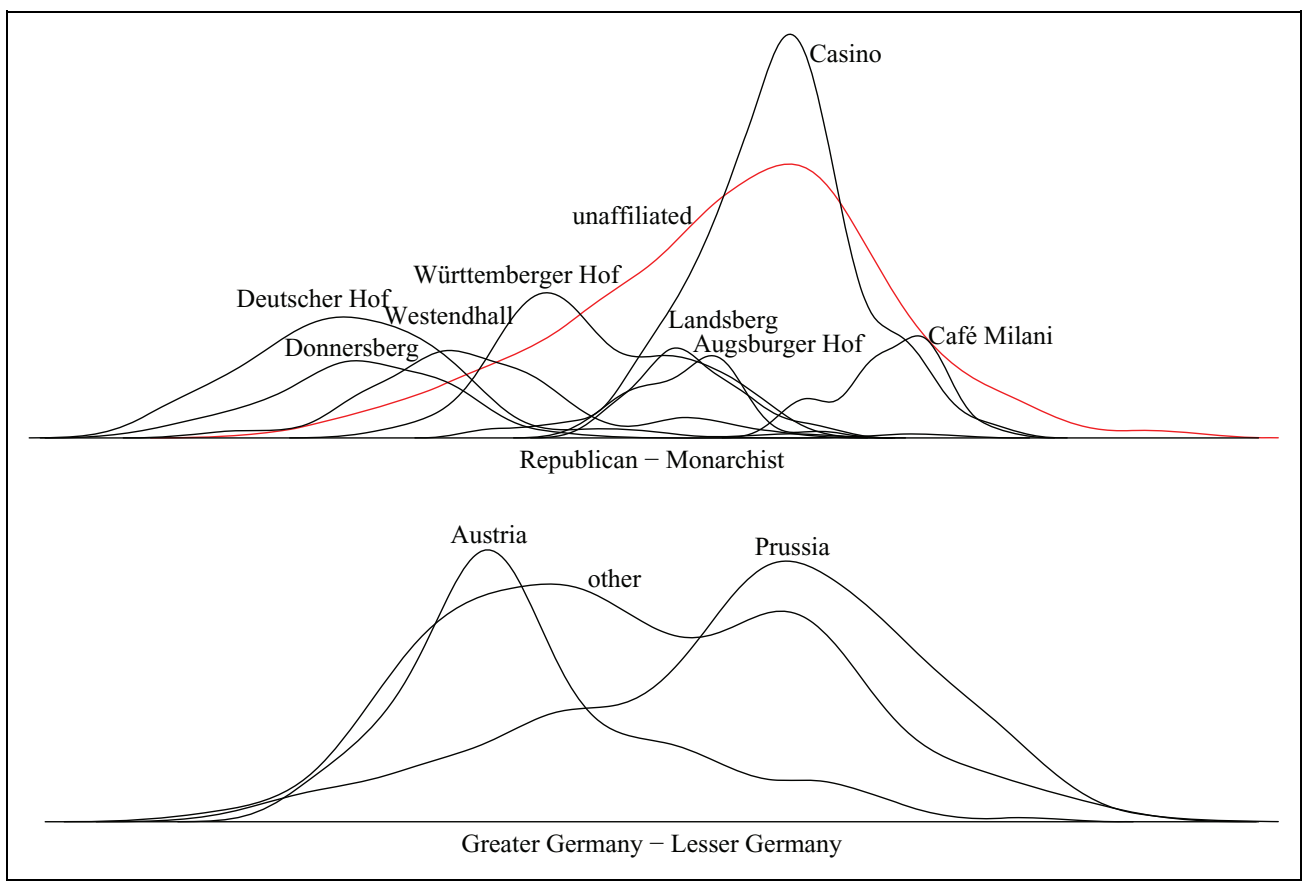

Figure 5. Distribution of MPs and parties on first and second dimension. Party medians on first dimension and $95 \% \mathrm{Cls}$ : $-\mathrm{I.59}[-\mathrm{I} .68$, - I.32] (Deutscher Hof), - I.50 [-I.60, - I.22] (Donnersberg), -0.97 [-I.08, -0.80] (Westendhall), -0.40 [-0.5I, -0.28] (Württemberger Hof), 0.17 [0.04, 0.3I] (Landsberg), 0.23 [0.04, 0.35] (Augsburger Hof), 0.67 [0.53, 0.77] (Casino), I.26 [I.08, I.38] (Café Milani).

This interpretation rests on fixing the locations of two roll calls (indicated by tick marks on the $x$ - and $y$-axis) which, according to historical scholarship, highlight the fundamental disagreements in the FA: the vote on the emperor's veto rights (Wigard, 1849: 4120), and the vote on Heinrich von Gagern's proposal to authorize the Provisional Central Power (the executive branch of the FA, to which Gagern had been elected cabinet leader in December) to enter negotiations with the Austrian government about the relationship between Austria and a future German state (Wigard, 1849: 4666).

The emperor's veto was one of the most contested constitutional issues. According to Mattheisen (1979: 133), it 'reflected the basic conflict between $[\ldots]$ an ultimately sovereign monarch and an ultimately sovereign people. In case the two should clash, which would finally prevail?' Liberals wanted to endow the emperor with an absolute veto on parliamentary legislation. Republicans pushed for a suspensive veto. The first vote on the emperor's veto was taken on 14 December 1848, but the issue remained unresolved until late March 1849 when, finally, a bargain was struck in which a group of liberal MPs consented to the suspensive veto in exchange for leftist's support of a Lesser Germany (Simon-Gagern pact, see section 3). We use the vote from 14 December to identify the first dimension as it pinpoints the fundamental struggle between the reformist and restorative forces.

The vote on Heinrich von Gagern's proposal on 13 January 1849 was chosen because it 'revealed for the first time the new balance of strength in the assembly' (Eyck, 1968: 357). Gagern's proposal to enter negotiations with Austria was an attempt to reconcile the desire by many FA members to unite all German-speaking territories with the reality that the Habsburg Monarchy would not relinquish most of its constituent territory. ${ }^{10}$ Gagern proposed a German federation without Austria but with close ties to it, a sort of confederation between both states, and he asked for the parliament's consent to enter a dialogue with Austria. Critics of Gagern's proposal argued that the FA did not have the right to exclude Austria from a German state (Eyck, 1968: 353-7). We use the vote on his programme to identify adherents of a Greater and a Lesser Germany. ${ }^{11}$

\section{MPs and parties along both dimensions}

Our scaling allows us to compare the recovered positions of MPs from different parties to canonical accounts of the parties' political inclinations given in the historical literature. Historians order the groups from left to right as follows: Donnersberg, Deutscher Hof, Westendhall, Württemberger Hof, Augsburger Hof, Landsberg, Casino and Café Milani (see section 3).

Figure 5 (top graph) shows only two deviations from the expected ordering: the Donnersberg party deviates from expectations as its median MP is to the right of Deutscher Hof; likewise, the median Landsberg MP is to the left of the median Augsburger Hof MP. In both cases, however, the exact ordering is uncertain, as the medians of the adjacent 


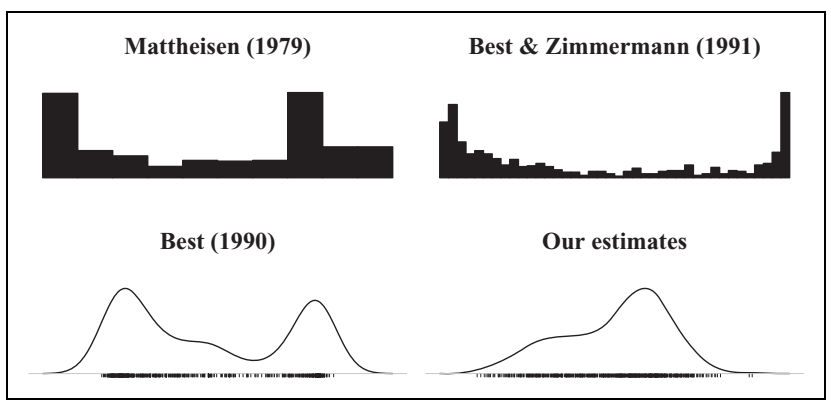

Figure 6. Distribution of MPs on first dimension (left vs. right) according to previous studies and our estimates. Best's (1990) estimates of MPs' positions were taken from his data set. Best and Zimmermann's ( 1991 ) estimates were taken from their Figure 5. Mattheisen's results are taken from Mattheisen (1979: 129). Tick marks underneath each kernel density plot indicate MPs' estimated positions.

parties are statistically indistinguishable (at the 5\% level). In all other cases, the medians of adjacent parties clearly differ, even after accounting for estimation uncertainty, as the non-overlapping credibility intervals show. MPs' recovered positions thus correspond quite well with the political inclinations of the parties they joined. Furthermore, the results suggest much overlap in political views between parties as well as diversity of views within parties. The same conclusions hold if we use party codings according to Koch et al. (1989).

The line-up of the parties also speaks to historical accounts of how the party system evolved over time (cf. Boldt, 1971; Eyck, 1968; Kramer, 1968). While the eight parties depicted in Figure 5 all existed from October through November 1848, we know that the first parties to develop were Deutscher Hof, Württemberger Hof, Casino and Café Milani (initially called Steinernes Haus). Subsequent splits led to Deutscher Hof MPs forming Donnersberg, Westendhall MPs seceding from Württemberger Hof, Casino MPs founding Landsberg, and Augsburger Hof MPs seceding from Württemberger Hof. Figure 5 reveals that, with the exception of Donnersberg, the splits all involved fringe MPs breaking away from their initial parties.

Regarding the territorial dimension depicted in Figure 5, we know that it cut across party lines with radical democrats strongly favouring a Greater Germany, and liberals and conservatives divided into Greater and Lesser Germans (see Figure 4; cf. Boldt, 1971; Botzenhart, 1977; Eyck, 1968; Kramer, 1968). Breaking down MPs by regional provenance, we find MPs from Prussia predominantly to one side and Austrians to the other, as Figure 5 (bottom graph) shows.

\section{Comparison with previous results}

In section 4 , we reviewed previous attempts to scale the FA's roll call record. These approaches used but a fraction of the available roll call record (Best, 1990; Best and

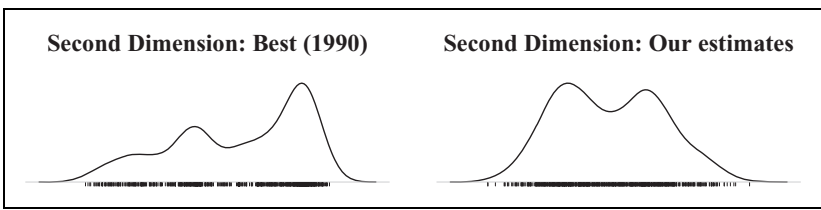

Figure 7. Distribution of MPs on second dimension (Greater vs. Lesser Germany) according to previous studies and our estimates. Best's ( 1990) estimates of MPs' positions were taken from his data set. Tick marks underneath each kernel density plot indicate MPs' estimated positions.

Zimmermann, 1991; Mattheisen, 1979), considered only a fraction of MPs (Mattheisen, 1979), employed restrictive (Mattheisen, 1979) or inappropriate (Best, 1990) methods for recovering MPs' positions, or treated MPs who were not present at the time of a vote as if they were (Best, 1990; Best and Zimmermann, 1991).

Figure 6 compares our estimates of MPs' positions on the first dimension to those of previous studies. Across all previous studies, the estimated positions display a bimodal distribution with most MPs clustering at the extreme poles of the scale. The centre is essentially empty. Substantively, such a distribution indicates highly polarized block politics with little potential for compromise. Thus, Best and Zimmermann (1991: 67, our translation) claim that their findings support a notion of a 'natural bipartism', providing evidence for a deeply divided parliament. Mattheisen similarly concludes that 'the distribution is sharply bimodal, suggesting a polarization of views' (Mattheisen, 1979: 129). Our estimates do not support these conclusions. The political centre was densely populated, and there is no evidence of a bimodal structure.

Regarding the second dimension, prior studies provide less evidence to which we could compare our results. Indeed, as fewer votes divided the parliament along this dimension, previous studies did not have much 'material' to scale MPs on this dimension (see section 4). Figure 7 compares our estimates to the only available evidence. Again, our results clearly differ from previous ones. Interestingly, they suggest that voting on the second dimension was polarized with two blocks of MPs voting against each other fairly consistently.

As a check of robustness, we created an animation showing the distributions of ideal points over time to account for the fluctuating membership in the FA (see the SI). ${ }^{12}$ The animation presents weekly updates of the distributions of ideal points, starting from 18 May 1848, which show that our conclusions regarding the nature of conflict on each dimension remain unchanged by turnover in membership.

Our ideal point estimates suggest a quite different interpretation regarding the nature of conflict and the potential for compromise than previous ones. On the first dimension, they suggest that even small alterations to legislative proposals could swing the vote of a substantial number of MPs, thus making it easy to find a middle ground, while on the 
second dimension they suggest that compromise was much more difficult. We believe this difference was due to the nature of the issues defining these dimensions. Unlike the issue of government, the question of including Austria did not allow for a middle ground. Heinrich von Gagern's proposal for a confederation notwithstanding, most MPs saw it as a choice of either in or out.

Finally, our results also speak to qualitative assessments about the nature of conflict in the FA. For example, they qualify conclusions drawn by Eyck (1968: 361) that 'on the two most important - and connected - issues, that of the ideological basis of the constitution and of state rights, there was a wide spectrum of views, facilitating compromise without any suspicion of horse-trading'. While this statement seems accurate with regard to the first dimension of conflict, it overlooks the polarization of views on the second dimension, which made compromise particularly difficult in the end.

\section{Discussion}

Our study demonstrates the existence of a basic space in a least likely case: an early revolutionary parliament. It shows that voting in Germany's first legislative assembly was characterized by two basic dimensions reflecting conflict over authority and conflict over territorial boundaries. MPs' positions vary considerably across both dimensions, between parties, and also within parties. Our estimates of MPs' positions contrast starkly with those produced by previous quantitative analyses; most importantly, they yield no evidence for polarization on the first dimension - unlike previous roll call analyses - but show, instead, that MPs were polarized on the second dimension.

What drives the low dimensionality of roll call voting? We believe that ideology is the most likely explanation for four reasons. First, for a revolutionary parliament, the FA hosted a remarkably large number of MPs with legal training. As observed by Eyck (1968: 95), half of all MPs either practised law as judges, public prosecutors or lawyers, or they held positions as higher civil servants for which legal training is a requirement (see also Botzenhart, 1977: 162). Such widespread knowledge of law should have enabled MPs to mould their general political ideas into coherent legislative proposals (cf. Jacobs, 2009; Ringe, 2005). Second, the fact that many MPs joined parties suggests that MPs who lacked subject knowledge had a chance to take cues from expert individuals. In particular, the party meetings may have provided untrained MPs with an opportunity to learn how their general values and beliefs translate into specific policies. Third, as pointed out by Ringe (2005), rapporteurs of legislative committees may influence how members interpret a policy proposal in ideological terms by emphasizing or downplaying particular aspects of it. This could have been the case here as well, as the FA installed standing committees early on and had them frequently report to the plenum. Finally, the diversity of MPs' recovered positions across both dimensions suggests that party pressure or agenda control were not the main drivers of the low dimensional structure in voting. If they were, we would expect to see tighter party clusters and less overlap between parties. In addition, the fact that liberal and conservative parties were split over the territorial question also suggests that party members could not be coerced to vote in a certain way.

While we believe that ideology was the main influence on MPs' voting behaviour, the processes which led to the observed votes were probably more complex than our simple scaling analysis suggests. Our approach in this article was to look at voting patterns at large, that is: across the entire lifespan of the FA. A closer look at specific episodes may reveal that other factors played a role in voting, too. For example, if parties served MPs' informational needs, members may have been willing to toe the party line and sacrifice some of their legislative freedom on specific votes. This could have been the case especially in the high period, when the parties were fully developed, the drafting of the constitution was in full swing, and votes on the floor were frequent and concerned mostly the first dimension. We leave such in-depth analysis to future research.

Our findings extend basic space research to an early revolutionary parliament. Previous research has identified only two instances in which a basic space gives a poor representation of legislative voting patterns (Poole and Rosenthal, 1991): the US Congress during the Era of Good Feelings $1816 / 24$ and in the early 1850s. Our results from an unsettled 'freshmen' parliament suggest that such instances may be even more exceptional than previously assumed.

\section{Acknowledgements}

The authors thank Heinrich Best for granting them permission to use his data set on the members of the Frankfurt Assembly. The authors also thank Simon Richter and Christian Spinner for their excellent assistance in the research.

\section{Declaration of Conflicting Interests}

The author(s) declared no potential conflicts of interest with respect to the research, authorship, and/or publication of this article.

\section{Funding}

The author(s) disclosed receipt of the following financial support for the research, authorship, and/or publication of this article: the Zukunftskolleg at the University of Konstanz through the Excellence Initiative of the German federal and state governments.

\section{ORCID iD}

Michael Herrmann (D) https://orcid.org/0000-0001-8070-5825 Ulrich Sieberer (D) https://orcid.org/0000-0003-4027-1393

\section{Supplemental material}

Supplementary material for this article is available online. 


\section{Notes}

1. The major English reference on the Frankfurt Assembly (FA) is Eyck (1968), other standard references include Botzenhart (1977), Hildebrandt (1986), Langewiesche (1978) and Ribhegge (1998).

2. We follow the convention in the historical literature in referring to the parliamentary groups as parties even though they do not represent parties in the modern sense.

3. Armstrong et al. (2014: 230) generally advise against imputing missing votes.

4. Mokken scaling is related to Rasch scaling (Rasch, 1961), which does have an ideal point interpretation (Poole, 2005: 28-9). We are unaware of work which proves that the Mokken method can be derived from an underlying preferential voting model.

5. The index lists 300 votes. One of these is the election of Archduke John of Austria as Vicar of the Empire. This vote presented MPs with more than two options, as several candidates stood for election. Our subsequent analysis is based on the 299 votes which presented MPs with a choice between two alternatives. Of these, 208 votes were upon request by at least 50 MPs, 90 were initiated by the presidium, and one, the vote for emperor, was a mandatory roll call vote.

6. This should not be surprising given the size of the parliament. Moreover, the FA instituted an attendance threshold of at least 150 members before a vote could take place.

7. This coding was taken from an extensive data set compiled by Best and Weege (1996). The data set is archived in the social science data repository at GESIS, study number ZA 8003.

8. This problem does not arise with one-dimensional ideal point estimation. As only two MPs need to be positioned, the distance between them only affects the scale of the recovered dimension.

9. Cutting lines should be interpreted probabilistically. They do not distinguish perfectly between those voting 'yes' and those voting 'no'.

10. On 29 January 1849 , the Austrian government declared that it did not wish to be part of a unitary German state (Hildebrandt, 1986: 224).

11. We further looked into the content of motions which had cutting lines similar to the vote on entering negotiations with Austria and confirmed that they pertained to questions over Prussian versus Austrian hegemony.

12. The dates at which MPs joined or left the FA were taken from the data set by Best and Weege (1996).

\section{References}

Aldrich JH (1995) Why Parties? The Origin and Transformation of Political Parties in America. Chicago, IL: University of Chicago Press.

Alemán E and Saiegh S (2014) Political realignment and democratic breakdown in Argentina, 1916-1930. Party Politics 20(6): 849-863.

Armstrong DAI, Bakker R, Carroll R, et al. (2014) Analyzing Spatial Models of Choice and Judgment with R. Boca Raton: CRC Press.
Best H (1990) Die Männer von Bildung und Besitz: Struktur und Handeln parlamentarischer Führungsgruppen in Deutschland und Frankreich 1848/49. Düsseldorf: Droste-Verlag.

Best H and Weege W (1996) Biographisches Handbuch der Abgeordneten der Frankfurter Nationalversammlung 1848/ 49. Düsseldorf: Droste-Verlag.

Best H and Zimmermann EJ (1991) Dimensionen politischer Konflikte: die Analyse von namentlichen Abstimmungen in Parlamenten mit dem Verfahren der Mokken-Skalierung. In: Best $\mathrm{H}$ and Thome H (eds) Neue Methoden der Analyse historischer Daten. Scripta Mercaturae Verlag, pp. 41-79. St. Katharinen.

Boldt W (1971) Die Anfänge des deutschen Parteiwesens. Fraktionen, politische Vereine und Parteien in der Revolution 1848. Paderborn: Ferdinand Schöningh.

Botzenhart M (1977) Deutscher Parlamentarismus in der Revolutionszeit: 1848-1850. Düsseldorf: Droste-Verlag.

Bowler S (2000) Parties and legislatures. Two competing explanations. In: Dalton RJ and Wattenberg MP (eds) Parties without Partisans. Political Change in Advanced Industrial Democracies. Oxford: Oxford University Press, pp. 157-179.

Bräuninger T, Müller J and Stecker C (2016) Modeling preferences using roll call votes in parliamentary systems. Political Analysis 24(2): 189-210.

Carrubba CJ, Gabel M and Hug S (2008) Legislative voting behavior, seen and unseen: a theory of roll-call vote selection. Legislative Studies Quarterly XXXIII(4): 543-572.

Carrubba CJ, Gabel M, Murrah L, et al. (2006) Off the record: unrecorded legislative votes, selection bias and roll-call vote analysis. British Journal of Political Science 36: 691-704.

Clinton J, Jackman S and Rivers D (2004) The statistical analysis of roll call data. American Political Science Review 98(2): 355-370.

Clinton JD and Meirowitz A (2004) Testing explanations of strategic voting in legislatures: a reexamination of the compromise of 1790. American Journal of Political Science 48(4): 675-689.

Converse PE (1964) The nature of belief systems in mass publics. In: Apter DE (ed), Ideology and Discontent. New York: Free Press, pp. 206-261.

Cox GW and McCubbins MD (1993) Legislative Leviathan: Party Government in the House. Berkley: University of California Press.

Curini L and Zucchini F (2012) Government alternation and legislative party unity: the case of Italy, 1988-2008. West European Politics 35(4): 826-846.

Desposato SW (2006) Parties for rent? Ambition, ideology, and party switching in Brazil's Chamber of Deputies. American Journal of Political Science 50(1): 62-80.

Diermeier D and Feddersen TJ (1998) Cohesion in legislatures and the vote of confidence prodecure. American Political Science Review 92(3): 611-621.

Dougherty KL and Heckelman JC (2006) A pivotal voter from a pivotal state: Roger Sherman at the constitutional convention. American Political Science Review 100(2): 297-302.

Eyck F (1968) The Frankfurt Parliament 1848-1849. London, New York: Macmillan \& St. Martin's Press. 
Godbout JF and Høyland B (2011) Legislative voting in the Canadian Parliament. Canadian Journal of Political Science 44(2): 367-388.

Guttman L (1944) A basis for scaling qualitative data. American Sociological Review 9(2): 139-150.

Häge FM (2019) Political conflict in Bismarck's Germany: an analysis of parliamentary voting, 1867-1890. Party Politics 25(2): 179-191.

Hansen ME and Debus M (2012) The behaviour of political parties and MPs in the parliaments of the Weimar Republic. Party Politics 18(5): 709-726.

Hildebrandt G (1986) Die Paulskirche. Parlament in der Revolution 1848/49. Berlin: Verlag der Nation.

Hinich MJ and Munger MC (1994) Ideology and the Theory of Political Choice. Ann Arbor: University of Michigan Press.

Hix S and Jun HW (2009) Party behaviour in the parliamentary arena: the case of the Korean National Assembly. Party Politics 15(6): 667-694.

Hix S and Noury A (2016) Government-opposition or left-right? The institutional determinants of voting in legislatures. Political Science Research and Methods 4(2): 249-273.

Hix S, Noury A and Roland G (2005) Power to the parties: cohesion and competition in the European Parliament, 1979-2001. British Journal of Political Science 35(2): 209-234.

Jackman S (2001) Multidimensional analysis of roll call data via Bayesian simulation: identification, estimation, inference, and model checking. Political Analysis 9(3): 227-241.

Jackman S (2015) Pscl: classes and methods for R developed in the Political Science Computational Laboratory. R package version 1.4.8. Available at: http://pscl.stanford.edu/.

Jacobs AM (2009) How do ideas matter? Mental models and attention in German pension politics. Comparative Political Studies 42(2): 252-279.

Jenkins JA (1999) Examining the bonding effects of party: a comparative analysis of roll-call voting in the U.S. and Confederate Houses. American Journal of Political Science 43(4): 1144-1165.

Kam CJ (2009) Party Discipline and Parliamentary Politics. Cambridge: Cambridge University Press.

Koch R, Stahl P, Hoede R, et al. (1989) Die Frankfurter Nationalversammlung 1848/49: Ein Handlexikon der Abgeordneten der deutschen Verfassungsgebenden Reichs-Versammlung. Kelkheim: H. Kunz Verlag.

Kramer H (1968) Fraktionsbindungen in den deutschen Volksvertretungen 1819-1849. Berlin: Duncker \& Humblot.

Langewiesche D (1978) Die Anfänge der deutschen Parteien. Partei, Fraktion und Verein in der Revolution von 1848/49. Geschichte und Gesellschaft 4(3): 324-361.

Mattheisen DJ (1979) Liberal constitutionalism in the Frankfurt Parliament of 1848: an inquiry based on roll-call analysis. Central European History 12(2): 124-142.

Mokken RJ (1971) A Theory and Procedure of Scale Analysis: With Applications in Political Research. The Hague: Walter de Gruyter.

Poole KT (2005) Spatial Models of Parliamentary Voting. New York: Cambridge University Press.
Poole KT and Rosenthal H (1991) Patterns of congressional voting. American Journal of Political Science 35(1): 228-278.

Poole KT and Rosenthal H (1997) Congress: A PoliticalEconomic History of Roll Call Voting. Oxford: Oxford University Press.

Pope JC and Treier S (2011) Reconsidering the great compromise at the federal convention of 1787: deliberation and agenda effects on the senate and slavery. American Journal of Political Science 55(2): 289-306.

Rasch G (1961) On general laws and the meaning of measurement in psychology. In: Neyman Jerzy (ed.), Proceedings of the IV Berkeley symposium on mathematical statistics and probability, Vol. 4, pp. 321-333. Berkley: University of California Press, June 20-July 30, 1960.

Ribhegge W (1998) Das Parlament als Nation.: Die Frankfurter Nationalversammlung 1848/49. Düsseldorf: Droste-Verlag.

Ringe N (2005) Policy preference formation in legislative politics: structures, actors, and focal points. American Journal of Political Science 49(4): 731-745.

Rosenthal H and Voeten E (2004) Analyzing roll calls with perfect spatial voting: France 1946-1958. American Journal of Political Science 48(3): 620-632.

Schonhardt-Bailey C (2003) Ideology, party and interests in the British Parliament of 1841-47. British Journal of Political Science 33(4): 581-605.

Spirling A and McLean I (2007) UK OC OK? Interpreting optimal classification scores for the UK House of Commons. Political Analysis 15(1): 85-96.

van Schuur WH and Kiers HAL (1994) Why factor analysis often is the incorrect model for analyzing bipolar concepts, and what model to use instead. Applied Psychological Measurement 18(2): 97-110.

Voeten E (2013) Clashes in the assembly. International Organization 54(2): 185-215.

Wigard F (1849) Stenographischer Bericht über die Verhandlungen der Deutschen Constituierenden Nationalversammlung. Stuttgart: Franz Wigard.

\section{Author biographies}

Michael Herrmann is senior lecturer in Political Science at the University of Konstanz, Germany. His research interests are mass and elite behaviour, political competition, the effects of electoral rules, and statistical modelling. His recent works have appeared in Political Psychology, Journal of the Royal Statistical Society Series A, and the Journal of Theoretical Politics, among others.

Ulrich Sieberer is professor of Empirical Political Science at the University of Bamberg, Germany. His main research interests are legislative behavior and legislative organization, institutional change, coalition politics, and judicial politics. His most recent work has been published in European Political Science Review, Journal of Legislative Studies, Legislative Studies Quarterly, Party Politics, and West European Politics. 